\title{
Philosophical Perspectives on Meaning in Literature and Life
}

\author{
Ravi Bhushan* \\ Associate Professor, Department of English, Bhagat Phool Singh Mahila Vishwavidyalaya, Khanpur Kalan, \\ Sonepat, Haryana, India \\ *Corresponding Author: Ravi Bhushan, Associate Professor, Department of English, Bhagat Phool \\ Singh Mahila Vishwavidyalaya, Khanpur Kalan, Sonepat, Haryana, India.
}

\begin{abstract}
The relationship between language and meaning has been defined in multiple ways by grammarians, philosophers and linguists. Unlike the western understanding of meaning as plural in nature the Indian aesthetics has looked at meaning as one holistic comprehensive entity. Bhartrhari (5th Century) considers language and thought as complementary and says that language is not the medium of meaning or thought. In fact according to him language, meaning and thought are same. An advocate of Monists' school of meaning, he accepts the holistic meaning of sentence as universal and termed it Sphota, where language and meaning are inseparable. Whereas German philosopher Edward Husserl said that meaning exists before language gives it a name. Another German philosopher Martin Heidegger and 20th century structural linguist Ferdinand de Saussure went on to say that language constructs meaning or the world. Gestalt theory of cognitive semantics considers perception as the initiator in the entire process of meaning formulation. The paper discusses differing perspectives on meaning and role of language.
\end{abstract}

Keywords: Meaning, Language, Sphota, Gestalt.

\section{MeAning OF MEANing}

The construction of meaning being the primary aim of any literary or philosophical expression, C.K. Ogden and I.A. Richards say in their book The Meaning of Meaning (1923) that the ultimate meaning is a result of language and thought used in constructing a narrative. They prioritize the influence of language on thought and meaning. Further in their 'theory of meaning' (1927) it is argued that a word does not have a singular meaning because different people define words differently. It simply means, meaning lies not in a word but it lies in the people.

\section{Gestalt TheORY}

According to Gestalt theory of cognitive semantics the process of meaning construction takes place using insight, information processing, memory and perception. Widely used for meaning determination and language processing, Gestalt theory says that process of meaning and comprehension starts with perception and final meaning is a result of wholeness of human experience. Human memory system acts as an active organized processor of information and prior knowledge plays an important role in learning and construction of meaning. It views learning as an internal mental process and focuses on intelligence building and cognitive developmental process.

\section{SAPIR-WHORF HYPOTHESIS}

The meaning in human speech (literature) depends on expression (spoken form), content (cultural meaning) and association between both. According to Sapir - Whorf hypothesis, structure and content of language determine the reality (meaning) perceived by its users.

\section{Phenomenology}

The theory of phenomenology (hermeneutics) has its own perspective on relationship of language and meaning. German philosopher Edward Husserl said that the language merely expresses inner meaning of a literary expression. Language per se has no meaning as such. Husserl treats internal and personal experience over and above language. He further says that an experience gets meaning not because of language but by perceiving a phenomenon as universal. An act of experience is independent of language; meaning pre- exists and is only given a name by language. However Husserl's opponents 
disagreed with his thesis and said that any kind of experience involves language which is social in nature. So how can an experience be personal or private in nature? Another eminent German philosopher Martin Heidegger wrote in his book Being and Time (1927) that all human experiences (meanings) are because of time and language. For him language is more than being an instrument of communication or device for expressing ideas. In fact language constructs the world and it contains the truth (meaning); reality 'unconceals' itself through language.

\section{SAUSSURE}

During the linguistic revolution of the $20^{\text {th }}$ century structural linguists Ferdinand-de-Saussure and Wittgenstein ended up saying that meaning is not simply expressed or reflected in language, in fact is produced by language. We have experiences because we have language which is social in nature. Hence all experiences are social and historical in nature.

\section{BHARTRHARI}

The Oriental (Indic) perspective on meaning has been presented by grammarian and philosopher Bhartrhari $\left(5^{\text {th }}\right.$ Century CE) in his book Vakyapadiya. He writes that the meaning of an utterance has to be inferred holistically taking into account its sphota and dhvani. Sphota in nutshell is indivisible and 'part less whole' which is neither constructed nor abstracted and dhvani is born out of sphota. The initial sound is sphota and the subsequent reverberations of sound are dhavani. According to him language, meaning and thought are one and the same. Language is not considered as the medium or carrier of meaning or thought, rather language and thought (meaning) carry each other. For him word and world are the same (sabadbrahaman). Since Bhartarhari subscribes to the Monists' School of meaning (akhand), for him sentence is the primary meaning bearing unit of human communication and it is complete in itself. Whereas Mimamsaka School of meaning, which follows atomistic theory of meaning (khand), treats sentence as collection of words (samghata); sentence meaning is the mutual meaning of its words (samsarga) and sentence is the sequence of words (karma) which decides the sentence meaning. Sentence meaning is given by pratibha (flash of understanding) which is holistic in nature. It is because of pratibha that some people understand the sentence meaning even before the utterance of the whole sentence. Therefore it is said that sentence uttered is already present in the hearer. Bhartrihari says that there can't be thought without language and knowledge without word in it, therefore word constructs the world. All human activity is based on language which is inseparable from meaning. The inseparable nature of language and meaning is the unitary principle and are distinct at instrumental level just to facilitate communication.

\section{BLOOMFIELD}

Discussing the complex nature of meaning and its relationship with language, American linguist Leonard Bloomfield (1887-1949) in his book Language (1933) wrote that understanding meaning in language study is uncertain and not easy; we use alternatives for meaning like 'demonstration', circumlocution (roundabout speech) and translation (equivalent form). He refers to the Mentalist School of meaning which believes that prior to the utterance of a linguistic form there occurs within the speaker a non physical process; a thought, concept, image, feeling, act of will etc. and on receiving the sound the hearer gets through an equivalent mental process. For a mentalist, language is the expression of ideas, feelings or volitions. Bloomfield further says that each linguistic form has a constant and specific meaning and similarly central (normal) and marginal (metaphoric or transferred) meaning.

\section{LANGUAGE AS MEDiUM}

Language for human beings is not an instrument or device; rather it is the medium in which brain waves gain shape and momentum. Since language always gets manifested either through our actual utterances or thoughts, definite meaning in language can only be for words defining countable or numerical objects. Whereas words which are defined based on general understanding of individuals do not convey a universal or definite meaning. Since language manifests thoughts, one has to critically understand the nature of one's language and thoughts to ultimately make meaning of life.

\section{CONCLuSion}

The acclaimed Hindi writer Munshi Premchand termed literature as a device to examine life which cannot be understood in a linear manner, rather life is multidimensional. Therefore multiplicity of 
meaning is the essential feature of literature (reflection of life) and this multiplicity is created and carried by language of human expressions.

\section{REFERENCES}

[1] Bloomfield, Leonard. Language. University of Chicago Press, 1933.

[2] Devy, G.N. Indian Literary Criticism: Theory and Interpretation. Orient BlackSwan, 2010.

[3] Eagleton, Terry. Literary Theory: An Introduction. Maya Blackwell, 1996.

[4] Matilal, B.K. The Word and the World. Oxford University Press, 1990.

[5] Ogden, C.K., and I.A. Richards. The Meaning of Meaning. Harcourt, Brace \& World, Inc.,1923

[6] Pillai, Raghvan K. Studies in the Vakyapadiya, Vol. I, Motilal Banarsidass, 1971.

\section{AUTHOR'S BIOGRAPHY}

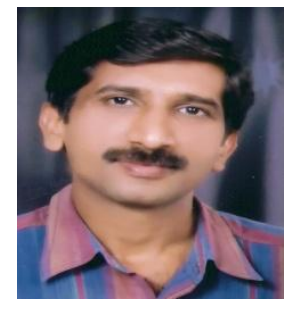

Dr. Ravi Bhushan, teaches English Language and Literature at Bhagat Phool Singh Mahila Vishwa vidyalaya, Khanpur Kalan, Sonipat, Haryana. Dr Bhushan has presented 55 research papers at National and International Conferences and has published 44 papers. He has authored a reference book titled Novels of William Golding: a Critical Study and Co-edited two books Affinities India and Korea: Past and Present and Mekong-Ganga Axis. He has completed UGC sponsored Major Research Project on status of ELT at primary, secondary and tertiary level in his home State of Haryana. His areas of interest are ELT, Cognitive Semantics, Communication Skills and Orality.

Citation: Ravi Bhushan. "Philosophical Perspectives on Meaning in Literature and Life”. International Journal on Studies in English Language and Literature (IJSELL), vol 6, no.11, November2018, pp. 1-3. doi:http://dx.doi.org/10.20431/2347-3134.0611001.

Copyright: (C) 2018 Authors. This is an open-access article distributed under the terms of the Creative Commons Attribution License, which permits unrestricted use, distribution, and reproduction in any medium, provided the original author and source are credited. 